\title{
Management Perspectives on Plastics Free Sport Facilities’ Beverage Service
}

\author{
Gord Watkin ${ }^{1}$, Cheryl Mallen ${ }^{1} \&$ Craig Hyatt ${ }^{1}$ \\ ${ }^{1}$ Department of Sport Management, Brock University, Canada \\ Correspondence: Cheryl Mallen, Associate Professor, Department of Sport Management, Brock University, \\ Canada. E-mail: cmallen@brocku.ca
}

Received: November 2, 2020 Accepted: December 10, 2020 Online Published: December 22, 2020

doi:10.5539/jms.v11n1p1 URL: https://doi.org/10.5539/jms.v11n1p1

\begin{abstract}
Due to a global environmental issue where plastic waste gets into our water resources, this research identified management perspectives on the implications of moving to plastic-free beverage services at sport facilities. The focus encompassed implications of both eliminating plastics and the introduction of biodegradable alternatives. Semi-structured interviews were conducted with a purposeful sampling of expert food and beverage managers employed at sport facilities with Canadian Hockey League tenants. Interview questions were developed using Transition Management Theory (Kemp, Parto \& Gibson, 2015), Attitude-Behaviour-Gap (Jacobs et al., 2018), concepts of consumerism (Koskijoki, 1997), and the call for sustainability business models (Borgert et al., 2018). Using thematic analysis, this study accessed the nuanced understandings of plastics use and the implications of implementing biodegradable alternatives. Results revealed inconsistent environmental management strategies: that government mandates are key; that there is a lack of public pressure concerning plastic waste management pratices; that bioplastic options are overlooked; that seven barriers impact the use of plastic alternatives; and, that mitigation and management of plastic is not their management role. In conclusion, much work is needed to move towards eliminating plastics and the introduction of biodegradable alternatives at sport facility concessions.
\end{abstract}

Keywords: sport environmental sustainability; sport and water management; sport, plastics use

\section{Management Perspectives on Plastics Free Sport Facilities' Beverage Service}

This manuscript outlines the critical issue of plastics in global waterways, including impacts on marine life, humans and climate change. The discussion then transitions to sport and the use of plastics. In particular, examples illustrate how sport is moving to mitigate plastics use at major sport events. A gap is revealed concerning the mitigation of plastics in sport literature. Next, two theories supportive of change are outlined, including Transition Management Theory (TMT) and the Attitude-Behaviour-Gap (ABG). This is followed by the methods used to examine the perspectives of sport facilities managers relative to plastic-free beverage services at sport facilities. The study encompassed the implications of both eliminating plastics (including plastic bottles, cups, lids and straws), as well as the introduction of biodegradable beverage-holder material options. The results, discussion, and conclusions illustrate these perspectives, and the viewpoints facilities managers have moving forward.

\subsection{The Critical Issue of Plastics in Our Global Waterways}

Water is unique from other natural resources as it can be misused, polluted or abused — but cannot be destroyed nor created - it only migrates (de Villiers, 2003). It has been noted, however, that humans are mismanaging this valuable natural resource by, for example, constructing dams (de Villiers, 2003); wasting water (Russell, 1997); and plastic pollution in water (Driedger et al., 2015; Jambeck et al., 2015; Miller et al., 2017; Royer et al., 2018).

Plastics are polluting water resources from streams and rivers to lakes and the world's oceans. Observable pieces of plastic in water are referred to as "marine debris" and as the "downstream cousin" of mismanaged land-based waste (Schuyler et al., 2018, p. 251). Plastic bottles and/or containers get into water by being dumped or carried by wind into sewage systems, rivers, and streams that feed into larger reservoirs (Shuyler et al., 2018). The plastics from the world's lakes and streams migrate into the oceans as they are downstream from nearly every terrestrial location, meaning mainland areas accumulating waste are higher than surface levels of the ocean or are "uphill" from mouths of waterways feeding oceans and lakes (Moore, 2019). This means that plastic waste in 
water flows towards - and then enters the world's oceans.

The oceans have a growing accumulation of more than 5.25 trillion pieces of plastic that has been dispersed within water by prevailing winds (Eriksen et al., 2014). Once there, plastics circulate via currents and accumulate into gyres, or into a large system of rotating ocean currents (Frumkin, 2016). These currents occur due to the synchronization of the Earth's rotation and winds that blow across the ocean's surface (National Geographic, 2019).

Plastics in our waterways have multiple impacts and this manuscript will offer examples of those impacts on marine wildlife and humans. To begin, a diverse range of turtle species have been found with their necks caught in plastic rings, rendering their ability to dive for food and breathe difficult —or at times impossible (Colabuono, Barquete, Domingues, \& Montone, 2009). Fish, too, have been caught with their stomachs full of plastic that subsequently kills them (Smith, 2018). This phenomenon is referred to as bioaccumulation, and is a widespread issue faced currently by all aquatic species. According to Frumkin (2016): "Bioaccumulation is the gradual accumulation of substances ... [that] occurs when an organism absorbs a substance at a rate faster than that at which the substance is lost by excretion or digestion" (p. 39). But why does marine wildlife ingest plastic? And what are the corresponding consequences on human health?

Marine wildlife ingest plastic because biofilms, or accumulated nutrients that naturally exist in aquatic ecology, collect on the surface of plastics (Carbery, O'Connor, \& Thavamani, 2018). As biofilms break down, they produce distinct odours commonly associated with nutrient-dense food sources (Kooi, Ness, Scheffer, \& Koelmans, 2017). Species, such as sea turtles, marine mammals, and seabirds are attracted to the smell-identifying and ingesting plastics they mistakenly perceived for nutrient-dense food. Relative to human health, consumption of fish for food that have bioaccumulated plastic within their stomachs and intestines, carry the toxicity of those plastics within their muscle tissues. Human beings are an extension of a widespread sequence of trophic spheres, as they consume animals for food like other predators (Frumkin, 2016).

Additionally, plastics in global water resources amplify the impacts of climate change, that have ramifications on both terrestrial and aquatic animals, and also human beings. One way this occurs is because "polyethylene is used regularly in the production of single-use disposable water bottles and is known to release additives such as bisphenol-A that releases hydrocarbon gasses that have adverse effects on environmental and human health" (Royer et al., 2018, p. 2). As polyethylene degrades, "the natural gases in which they are synthesized are released which contribute to atmospheric warming synonymously as polymers fragment into smaller units, increasing the surface area of exposure" (Royer et al., 2018, p. 4). Another example is that the degradation of plastics contributes to polychlorinated biphenyls (PCBs) and polycyclic aromatic hydrocarbons (PAHs) that are "flame retardants with retentive capabilities" (Teuten, Rowland, \& Galloway, 2007, p. 16) being released into water. As the climate continues to warm, plastics in the water absorb the warmth causing emission levels to rise (Royer et al., 2018).

Plastics in global waterways also impact human water management systems presently in place to provide safe drinking water. This is because the toxins from microplastics permeating throughout drinking water cannot be filtered out by existing municipal water management systems established to safeguard water for human consumption (Mason et al., 2016; Gaied et al., 2017). For instance, Mason et al. (2016) found microplastic particulate pollution in municipal wastewater across 17 water treatment facilities in the US. This means the municipal tertiary filtration systems are ineffective when it comes to reducing micro-particulate levels accumulating within water consumed by humans.

Thus, any use of plastics could contribute to this problem, including use of plastics for sport events. The United Nations, therefore, has noted that human beings need to mitigate the environmental impacts of plastics in water resources (Brundtland Report, 1987). Following this call, the focus now transitions to how sport is mitigating the use of plastics.

Sport has moved to identify ways to remove traditional platics (produced using fossil fuels) and to encorporate bioplastics (items made from renewable biological sources) (Siegel, 2019). Bioplastics have the ability to biodegrade, and are typically comprised of biomaterials such as woodchips, vegetable oils and fats, recycled food matter, and sawdust (Siegel, 2019). For instance, in 2017 Target Field (Minnesota, USA) offered compostable drinking cups comprised of corn starch resin (CBS, 2018); Tottenham Hotspur (English Premier League) eliminated plastic straws, stir sticks, cutlery, and some plastic packaging at their games (UN Environment Programme, 2018); and Twickenham Stadium (in London, England) utilized a reusable, deposit-incentivised fan cup for purchase during rugby games. A deposit is placed on the cup upon purchasing the first beverage and can be returned for a refund and sterilized or, fans can forgo their deposit and keep it as a 
souvenir (Twickenham Fan Cup, n.d.).

Examples of sport introducing spherification technology to eliminate the single-use water bottle can be found. For example, Skipping Rocks Lab (https://www.advancelondon.org/smes/skipping-rocks-lab/) used this technique to create the Ooho water pod-whereby water is contained in a round, bubble-like edible pod. The pods consist of brown algae and calcium chloride that can be altered in colour and flavour to accommodate a plethora of consumer preferences. It is cheaper to produce than single-use plastic bottles, is edible or biodegradable (biodegrades in less than three weeks) and possesses nutritional benefits when the casing is consumed, including protein, fibre, and access to vitamins and minerals (Notpla, n.d.). The Ooho, was utilized in England's 2018 Harrow Half-Marathon and at the 2019 London Marathon (Hardy \& Skopelity, 2019) - given to athletes at the start/finish lines and at hydration stations (Hardy \& Skopeliti, 2019).

Overall, plastics have been noted as polluting global waterways and examples illustrated how this type of pollution impacts marine wildlife and humans. Further, sport was noted as demonstrating movment away from traditional plastics with the introduction of bioplastics and incorporating mitigation strategies to eliminate waste. Not all sport events and facilities, however, are enacting this trend, which is interpreted to be in the primary stages of development. We will now transition to review the guiding manuscripts from the sport management literature on the topic.

\subsection{Academic Literature on Sports Plastics Use}

Mallen, Stevens and Adams (2011) investigated literature pertaining to environmental sustainability (ES) in sport journals from 1987-2008, finding that 17 of 4,639 peer-reviewed documents addressed the topic. Mallen (2018) then examined 3700 more manuscripts within 21 sport management journals and found an additional 53 manuscripts on the topic published from 2009 to 2015. This represents a $311 \%$ increase in publications on the topic within this sport journal sampling. The sport and ES literature extends to a variety of topics, such as encompassing climate change and its subsequent impacts on sport tourism (Gjuroska \& Pantekovska, 2018); environmental communications (Spector et al., 2011); intentions and outcomes of those communications (Dioguardi, 2012); the carbon footprint of sport tourists (Wicker, 2018); environmental impacts of small-scale sporting events (Gibson, Kaplanidou, \& Kang, 2012) and major sporting events (Paquette, Stevens, \& Mallen, 2011).

Few studies on sport and water were found - and none on sport and the plastics-water issue. Kellett and Turner (2011) examined community sport facilities in Australia and water management policies and practices concerning water consumption. They concluded that sport could act as "a model for self-regulatory institutions" (p. 155) if reactive action was replaced with planned water management strategies. Phillips and Turner (2014) developed a teaching note for instructors concerning sport and water management in Australia. Meanwhile, Harder-Lauridsen, Kuhn, Erichsen, Mølbak and Ethelberg (2013) examined water pollution on triathlon athletes, particularly the gastrointestinal impacts. Nikolic, Steffen and Bilic-Zuller (2017) also examined water pollution and sailors and the health risks posed by the water pollution at the 2016 Olympic Games held in Rio de Janeiro.

There is a gap in the sport management literature on sport, plastics use, and plastics pollution in waterways. This gap exists despite a body of academic literature published outside of sport that reflects an ideology that mitigating plastic consumption at the consumer level would provide the greatest environmental benefit - even though it requires the proliferation of a cultural change (Andersson \& Batemen, 2000; Auger \& Devinney, 2007; Bansal \& Gao, 2006; De Pelsmacker et al., 2005; Kallio \& Nordberg, 2006). The G7's Innovation Challenge to Address Marine Plastic Litter (2018) urged the proliferation of this cultural change in all industries.

There are several theories that relate to such cultural change. Two such theories were selected and outlined below as they can be applied directly to sport and environmental change. The first is transition management theory (TMT) and the second is the theory of the attitude-behaviour-gap.

Transition management theory (TMT) involves change and its impacts. Kemp et al. (2005) developed this theory which "is based on the notion that sustainability requires ongoing social and organizational processes of adaptive change, which in turn require innovation" (p. 484). TMT is comprised of several elements: (i) policy integration; (ii) common objectives and decision-making criteria; (iii) processes for system innovation; and (iv) mechanism for implementation via a variety of policy instruments. Kemp et al. (2005) suggested that long-term implementation can only occur when organizations identify how policies can be integrated within frameworks with an established, gradual timeline that permits cultural embodiment by constituents of that organization. That is, the human capital of organizations must adopt the principals; and as well, organizations must have congruent alignment of their vision, mission, and operational protocol with adaptive parameters that permit change. A cultural shift takes time (Kemp et al., 2005) and the TMT provides support for an ability to enact change. 
Next, Koskijoki (1997) purported consumption involves the selection, purchase, use, maintenance, repair, disposal, and recycling of any product/service, as opposed to their design, production, and marketing. This definition highlights that consumers share a responsibility in the life-cycle of retail products. The Attitude-Behaviour-Gap (ABG) examines the disconnect between motivations, purchase intentions, and actual consumption by consumers (Jacobs et al., 2018). The ABG focuses on the attitudinal shifts in consumers predicated on barriers to consumption (Auger \& Devinney, 2007; De Pelsmacker et al., 2005; Lane \& Potter, 2007). In order to achieve an ideological shift, a full understanding is needed of the related conditions and circumstances of goods and services rendered (Sproles, Geistfeld, \& Badenhop, 1978).

Before we outline the methods, it is important to note that in a process of change, greenwashing has been known to arise. Auger and Devinney (2007) defined greenwashing as the practice of making unsubstantiated or misleading claims about the environmental benefits of a product, service, technology or company practice. Greenwashing can make a company appear to have adapted to be more environmentally friendly than they actually are. Consequently, greenwashing can mislead consumers.

This manuscript now transitions to examining how sport can be part of the solution for the plastics-water issue. The methods, results and discussion, along with the conclusions are presented specifically for an examination of sport facility managers' perspectives on the implications of moving to plastic-free beverage services. The focus encompassed the implications of both eliminating plastics (including plastic bottles, cups, lids and straws), as well as the introduction of biodegradable material options.

\section{Methods}

This research was guided by three research questions:

Research Question 1: What practices guide those in beverage services at sport facilities?

This question was framed with the TMT element of policies (Kemp, Parto, \& Gibson, 2015), along with the definition of consumerism by Koskijoki (1997) that focused on interactions between consumers and their physical and social environments. The person doing the procuring (i.e., the Concession Manager) is the "customer"; spectators were addressed as "patrons".

Research Question 2: What are the objectives and decision-making criteria concerning plastics currently and into the future at sport facilities? This question was framed with the TMT element of objectives and decision-making criteria (Kemp, Parto, \& Gibson, 2015), along with the ABG that focused on implementation issues, including options, access, barriers and opportunities (Jacobs et al., 2018).

Research Question 3: What are the necessary mechanisms for implementation via a variety of policy instruments to make innovations a reality? (the implications of change). This question was framed with the TMT element of mechanisms to make innovations a reality (Kemp, Parto, \& Givson, 2015). Further, the framework was influenced by Borgert et al. (2018), who collectively called for ideological shifts towards sustainable business models. The research questions sought understanding of the realities of such a shift.

Purposeful sampling was utilized. Patton (2002) supported the use of purposeful sampling as being involved in a process with a focus on "information-rich" participants to "illuminate the questions under study" (p. 230). The participants were from sport facilities that hosted Canadian Hockey League (CHL) games. The league is comprised of the Quebec Major Junior Hockey League (QMJHL), the Ontario Hockey League (OHL), and the Western Hockey League (WHL). Selecting arenas that housed teams within CHL competition provided ample opportunity to recruit prospective participants from the 52 facilities that were situated within Canada. This sample ensured that the facilities were comparable due to standards established by the league.

Participants were comprised of food and beverage managers or concession managers at a sport facility. Participants were considered to be experts with respect to their role, consistent with Okoli and Pawlowski (2004), who stated that participants were considered to be experts if they occupied managerial positions within their institution. A total of 10 ( or 19.23\%) of the potential population was interviewed when saturation was experienced (Morse, 2015). The number of interviews was consistent with the research design of Baldwin (2010).

\subsection{Data Collection}

This research employed semi-structured interviews and document collection witin the data collection process (Patton, 2002; Gallella, 2013; Glense, 2015) using Skype/FaceTime or in person (with one in-person interview held in the concession stand area and others in their designated office prior to Covid-19). Semi-structured interviews, according to Patton (2002), can capture the perceived view of the interviewee including to learn their 
terminology and judgements based on their perceived social reality, which is further based on their experience, and to capture the complexities of their individual perceptions and experiences. The participants had 166 years of food and beverage service management combined experience, ranging from five (P-8) to over 35 (P-7) years of experience.

The interviews were guided by an interview guide. Patton (2002) purported an interview guide aided the facilitation and developmental processes of data collection through semi-structured interviews. See Appendix A for the interview guide.

Interestingly, participants could not offer empirical documents that pertained to waste output or diversion in relation to their food and beverage activities, recyclability rates, or empirical documents regarding their environmental practices - they simply did not have such documents or know where to access this information. Relevant documents, however, were used to contextualize the data, including the G7's Innovation Challenge to Address Marine Plastic Litter (2018), as well as documents on initiatives related to corporate beverage packaging that specifically included PepsiCo and Coca-Cola - the two main companies that had contracts with the beverage services at the sport facilities.

After the interview data was transcribed, member checking was completed. Stake (1995) described member checking as an interpersonal process entailing that the researcher and participant review the transcripts "to ensure the data collected is accurate and palatable" (p. 115). The member checking process in this research involved sharing the transcript of each interview with the expert participant to ensure data collected was contextually framed as intended by each participant. The participants received the transcript in an email and no participants refuted their transcript.

\subsection{Data Analysis}

The defining data analysis units involved the use of thematic units. According to Glesne (2014), thematic analysis is the process of searching for themes and segregating data into codes or labels. Also, Gibbs (2007) implied that "researchers can explore how categories or thematic ideas are represented by the codes" (p. 48). Further, Smith (1992) deemed that "the term thematic connoted the analysis of story-like verbal material, and the use of relatively comprehensive units of analysis such as themas, themes, combinations of categories, motifs, images and thoughts" (p. 4). There was a search for themes during each of the three readings of the data in the analysis process as supported by Glesne (2014), Gibbs (2007) and Smith (1992).

Confidentiality was promoted in this research with the use of pseudonyms. Glesne (2014) suggested the use of pseudonyms in the pursuit of anonymity within qualitative research. Stake (1995) also called for pseudonyms to be coded to enhance efficiency in filing documents. Suggestions from both Glesne (2014) and Stake (1995) were followed by providing each participant with a coded pseudonym. For instance, participant one will be referred to as $\mathrm{P}-1$.

\section{Results and Discussion}

This research identified sport facility concession managers' perspectives vis-a-vis moving to plastic-free beverage services. The focus encompassed the implications of both eliminating plastics (including plastic bottles, cups, lids and straws), as well as the introduction of biodegradable material options. The results and discussion will now be outlined based on each of the three research questions.

\section{RQ-1: What practices guide those in beverage services at sport facilities?}

A key theme arose whereby the managers were meeting the requirements with regard to plastics as established by municipal mandates - but there were differences in practices for sport facilities within the various regions of the country. This meant that universal environmental practices concerning plastics management were not utilized. This finding aligns with the G7 Innovation Challenge to Address Marine Plastic Litter objective that innovative social or technological solutions for a more consistent sustainable management of plastics are needed in order to increase resource efficiency - particulary to enhance waste management of plastics to avoid marine litter (G7, 2018).

It was clear that regional distinctions guided and impacted practice. This research advanced the differences as being within two key groups of municipal/provincial policies_-including "amplified" and "relaxed" recycling policies.

The "amplified" practices were defined as involving advanced policies of practice with strong directives guiding managers relating to the collection and post-collection management of plastics. This led to greater consistency in the handling of plastic waste with less, if any, ambiguity surrounding the management of plastic waste. For 
example, $30 \%$ of the participants (P-7, P-8, P-9) within an "amplified" setting of practice suggested that they have seen advances in the public enforcement of plastic recycling practices within their region that have positively influenced the way managers currently operate within their roles. P-7, a manager for over 25 years, has witnessed a transformative shift in daily operations due to the implementation of reformed recycling practices enforced within their province. When asked about the attitudes of practitioners concerning plastic waste in the past, P-7 said: "In this service, nobody particularly cared about waste of their products in the beginning of my career." Recycling practices were noted now as being reformed by the government, including the incineration of plastic for the production of steam energy. A total of $30 \%$ (P-7, P-8, P-9) indicated that steam is used for the production of their ice. This finding was interpreted to mean that these participants acknowledged and managed plastics as an urgent environmental problem (Bansal \& Gao, 2006).

Meanwhile, the "relaxed" practices were defined as lenient, with minimal directives pertaining to required management practices, thus offering nominal edicts for handling specific plastics. This leads to ambiguity in what and how plastics were to be managed. Managers within "relaxed" settings exhibited a less-comprehensive understanding of the fate surrounding plastic waste once it was collected and removed during waste collection. This group supported scholarship by Bansal and Geo (2006) that depicted organizations are aware of the increasing urgency of environmental problems but are slow to react.

It was noted that whether in an "amplified" or "relaxed" environmental policy region, the participants noted it was government regulations that were the key influencer dictating practices. This finding meant that the participants were not applying the work by Koskijoki (1997) that a consumer (customer) has a responsibility for the entire lifecycle of a product, including its disposal and decomposition. Instead, the participants relied on government mandates to dictate the extent and level of engagement in which ES practices were applied. This finding is outlined further below.

\section{RQ-2: What are the objectives and decision-making criteria concerning the use of plastics currently and into the future at sport facilities?}

Every participant agreed that they were aware of, and had permission to purchase and implement, biodegradable alternatives at their respective facility. A total of $40 \%$ of the participants offered at least one biodegradable option. For example, P-2 provided biodegradable coffee cups (non-waxed), bioplastic stir-sticks, and cardboard coffee sleeves, along with bioplastic lids for beer pints, but the pints themselves were single-use plastic. A total of $30 \%$ of participats also offered bioplastic lids for their single-use plastic beer pints. There were noted barriers, however, that influenced objectives and decision-making concerning plastics used for food and beverage services. Seven key barriers in the process of deciding to use plastic alternatives are now presented.

First, all of the managers revealed there to be a general lack of biodegradable options from their current vendors. When asked about mandates from superiors surrounding purchasing from any vendor, all managers agreed they had the freedom to seek products from other vendors and acknowledged the existence of alternatives that are biodegradable but not offered by the vendor currently utilized. This suggested an awareness of environmentally sustainable options regarding plastics, as well as the autonomy to purchase them. The finding was interpreted with the TMT to be a microcosm of a culture of convenience relative to use of their current vendor. A movement toward utilizing currently proven biodegradable options that are in the marketplace was positioned as, generally, only likely to happen if they are offered by their current key vendors. This was supported by P-3 that stated that advancing the environmental management of plastics was out of their control. This participant indicated:

"Where I struggle with single-serve is... what can I control? I do my best. What I can't control is bottling companies. The thick plastics that they come in, for our slushy kits, lids and straws and that sort of thing. Corporately, there has to be a change before I have any impact".

Second, a barrier involved not being able to acquire all of the necessary components for bioplastic alternatives from their key vendor. For instance, P-2 did not offer a bioplastic lid for their hot beverages, stipulating one was not available. Further, P-3 indicated that their vendor did not have biodegradable lids or straws that corresponded with the biodegradable cup the manager already purchased in mass quantities. There were, thus, compatability-related challenges in making a beverage container (with lids and straws) entirely biodegradable.

Third, a barrier existed where not all supply companies offered the same types or variety of biodegradable alternatives (P-1, P-2, P-3, P-4, P-5, \& P-10). Due to this lack of variety, costs of acquiring these products were described to be higher. Fourth, a barrier involved the durability or rigidity of these products. P-1, P-2, P-3, P-4 and P-5 all implemented a paper straw as their initial biodegradable alternative offering in their concessions. These participants expressed that their patrons were dissatisfied with the taste the straw left in their mouth, and that it broke down before they completed their beverage. P-4 stated: "It tastes like you are licking a cardboard 
box. Its pasty and rather off-putting". Interestingly, the use of a fully bioplastic straw was also not a complete solution. According to P-5, "Customers think its still plastic, there isn't a paper sleeve or nothing to tell people this is actually a good thing". These findings support the notion suggested by P-3, who explained vendors of biodegradable products need to offer accompanying environmental communications.

Fifth, a barrier revealed spherification technology sanitation issues. Not a single participant felt it was feasible to implement that particular technology because they foresaw sanitation issues. Participants were impressed with the concept, but in the short-term it did not appear to be an option for their concessions. Sixth, a barrier was that every participant had a corporate partnership with a beverage company resulting in use of single-use bottles, and in select cases, additional fountain beverages. Participant agreements were deemed to be exclusive as, for example, no facility offered both Coca Cola and PepsiCo. Further, every participant operated under contracts that were inclusive of selling a quota of products to satisfy goals within these agreements. The products expected to be sold were described as single-use plastic bottles containing either soft drinks or water. However, no participant had the option to purchase bioplastic alternatives for single-use bottles by any of their key corporate partners. This is significant because single-use bottles were consumed more then any other beverage and container respectively.

According to PepsiCo's website, the company has committed to a $35 \%$ reduction in virgin plastic production and use by 2025 (PepsiCo, 2020). Barrett (2018), indicated that PepsiCo is committed to producing partially-compostable bioplastic bottles within their partnership with other major utilizers of single-use plastic; including Danone, Nestle, and Origin Materials, along with partnerships with federal governments (Canada, Ghana, Indonesia and United Kingdom), environmental organizations (World Wildlife Fund International, World Resources Institute, Geminicorp Recycling and the Global Environmental Fund) and economic institutions (World Economic Forum, World Bank, Morgan Stanley, Pew Charitable Trusts and SYSTEMIQ Ltd.). This activity fits within the goal of blending different industrial spheres across several levels within the network hierarchy to change the way plastic is produced, utilized, and recycled/repurposed to mitigate marine plastic pollution (World Economic Forum, 2018). Similarily, the Coca-Cola website reflected a timeline and goals with partnerships with work towards a portion of plastic bottles being recycled plastic and moving to plant-based products (Coca-colacompany.com, 2018). Coca-Cola did not express as much detail on their website for full comparisons to be made.

An interpretation of the the findings is that instead of utilizing bioplastics already available in the marketplace - but not within the currently utilized supply chain-participants are waiting for their major suppliers to offer bioplastic products before replacing their current plastic concession service products.

The food and beverage managers have reasons to be optimistic regarding future bioplastic options being available from the current corporate partners that could eliminate many of the barriers outlined above. Yet, it has been noted by Borgert et al. (2018) that corporations producing sustainable products tend to only satisfy a small component of necessary shifts required to improve environmental practices. Government mandates, thus, were positioned as necessary to enforce plastics management legislation.

Finally, the seventh barrier concerned the incineration of plastic which intimated that purchasing biodegradable options were not necessary. P-9, however, was steadfast in their explanation that it was not sufficient just to incinerate plastic and keep producing it. P-7 further iterated that: "Incinerating plastic is great, but it still doesn't fix the issue. It just makes it palatable. Virgin plastics are encouraged for production in my opinion if we just keep justifying its existence by using it for energy". The generation of energy from plastics, therefore, was interpreted as a current barrier in the decision-making process to move to bioplastic options.

Overall, the ABG focused on attitudinal shifts in consumers pertaining to consumption (Auger \& Devinney, 2007; De Pelsmacker et al., 2005; Lane \& Potter, 2007) and an ideological shift to eliminate or mitigate plastics at sport facility concessions was not found. This was interpreted to be caused by the multiple barriers outlined above.

\section{RQ-3: What are the necessary mechanisms for implementation via a variety of policy instruments to make innovations a reality? (the implications of change).}

Academic literature in environemental sustainability reflects an ideology that mitigating plastic consumption would provide the greatest environmental benefit — but it requires the proliferation of a great cultural change (Andersson \& Batemen, 2000; Auger \& Devinney, 2007; Bansal \& Gao, 2006; De Pelsmacker et al., 2005; Kallio \& Nordberg, 2006). Part of this cultural change in consumer behaviour arises from awareness of the situation. All of the participants were found to be aware of current environmental challenges, particularly ones attributed to single-use plastic beverage containers, and subsequent approaches to mitigating potential waste. 
Importantly, every participant suggested that shifts toward environmental management of plastics were not only feasible but also inevitable in their opinion. The participants offered a variety of mechanisms requisite to achieve innovative approaches to procuring beverages within their respective facility. Their suggested strides towards environmental options are redolent of Borgert et al. (2018) and reflected components of sustainable business modelling. Importantly, no signs of greenwashing were noted when discussing their approaches. The concept of greenwashing, as defined by Auger and Devinney (2007), is the practice of making an unsubstantiated or misleading claim about the environmental benefits of a product, service, technology or company practice. Greenwashing can make a company appear more environmentally friendly than they actually are, allowing for patrons to be misled into supporting corporations that are not practicing environmentally-centered protocol and policy. No cases of greenwashing concerning plastics use at the sport facility concessions under examination were found or expressed as an issue by the participants.

There were three key mechanisms suggested to advance a culture of environmentalism at the sport facilities including government environmental policy, public pressure, and the development of transparent environmental communications. Each is now outlined.

The mechanism for encouraging the implementation of innovations for plastics free products offered by corporate partners was noted as government policy. This important finding confirms the findings in RQ-1 that directly proposed that governments were responsible for advances in environmentalism and that the managers were not sharing what Koskijoki (1997) indicated was a life-cycle responsibility for products. P-3 explained that government mandates were necessary, as the priorities of corporations are clear and laid out in corporate agreements between the corporate partner and sport facility; which was and remains all about forecasts surrounding units sold. P-1, P-2, P-3 and P-6, however, suggested that if more alternatives flooded the market (encouraged by government mandates), it would improve the quality of products, such as bioplastic options, due to the competition. None of the participants indicated that they were lobbying the government to advance environmental mandates.

Next, participants noted that public pressure was a necessary catalyst to reform policies around plastic waste or universally understood plastic management practices. Participants indicated that there was a lack of consistent public pressure on managers to force advancements in the mitigation and management of plastics. P-3 was the only participant to attest to some pressure from millennials that ridiculed the use of plastic more than any patron demographic. Meanwhile, P-6 stated: "We got an older age demographic, they don't really talk about environmental challenges, let alone inquire about them". Collectively, it was found that the managers do not have enough public pressure on them to force 'a call to heed' when it comes to such environmental advancements (except P-3). This is interpreted to mean that consistent public pressure campaigns are needed as a mechanism for a movement away from single-use plastics and a movement towards bioplastics at sport facility concessions.

And additionally, transparency within environmental communications was deemed by the participants as requisite (i) to broaden understandings of ES in consumers and practitioners; (ii) to establish intentions of environmental goals; and, (iii) to provide measured outcomes of such initiatives. Transparency was determined to be an important mechanism of accountability. Participants noted that clear and transparent environmental communications were not always communicated to managers by employers, nor by managers to their patrons. All participants indicated that they had received some type of environmental communication and utilized them within their respective facility, mostly on the fronts of three-bin recycling areas (which are three bins conjoined, with each bin being for a different material such as plastic, paper and waste) and bulletins forwarded to employees in the staffing offices. However, no participant had attended meetings regarding environmental initiatives. Interestingly, one participant illustrated a lack of transparency concerning environmental activities at privately managed sport facilities. P-4, perceived their activities to be in alignment with expectations of their employer - but was not aware of initiatives being conducted by their employer in other sport facilities. When specifically asked about the initiatives, P-4 was impressed but stated that "my employer would not behave that way". Ironically, the venue management firm responsible for the initiative, was in fact P-4's employer. The findings represented a limited overall environmental communication platform and a lack of transparency that was deemed as necessary moving forward.

\section{Conclusions}

Plastic waste is a global issue that is impacting global water resources. Plastics utilized by any source, including at sport facility concessions, have the potential to contribute to this global environmental issue. This research identified management perspectives on the implications of moving to plastic-free beverage services at sport 
facilities, including the implications of both eliminating plastics (including plastic bottles, cups, lids and straws) and the introduction of biodegradable alternatives.

Semi-structured interviews were held with a purposeful sampling of expert food and beverage managers employed at sport facilities. Three research questions guided the study and the interview questions were developed utilizing the TMT (Kemp, Parto, \& Gibson, 2015), the ABG (Jacobs et al., 2018), along with the concepts of consumerism (Koskijoki, 1997), and the call for ideological shifts towards sustainability business models (Borgert et al., 2018). With the use of thematic analysis, this study was able to access the nuanced understandings of plastic use, and the future implications of implementing biodegradable alternatives through the perspective of individuals responsible for procuring beverages at the examined sport facilities.

There were five key conclusions from this study. The first conclusion was that sport food and beverage managers do not consistently practice ES management strategies regarding plastics.

Universal management practices were not found to be utilized at the sport facility concessions.

Sport facility managers were influenced by regional "amplified" or "relaxed" government recycling practices concerning plastics. This was interpreted to mean that the behaviour of the managers differed based on their locale and it was predicated on government mandates.

The second conclusion was that government mandates are key to advancing change concerning the use of plastics at concession areas within sport facilities. Unaminously and repeatedly, the participants indicated that the mitigation of plastic use at concessions was predicated upon government plastic waste management mandates. Guiding government mandates were noted as being able to develop and enforce consistent ES policies around plastic use and disposal. Further, these mandates were necessary to influence the sport facility corporate partners to offer a full range of alternatives that could replace single-use plastics. Such options could then be utilized by the concession managers.

The third conclusion was that managers feel that there is a lack of public pressure for adapting policy and waste management practices related to plastics use. Along with government mandates, public pressure was noted as a necessary catalyst to reform public policy around plastic waste or universally understood plastic management practices. The participants noted a current lack of public pressure to adapt to plastics-free concessions.

The fourth conclusion was that bioplastic alternatives are being overlooked if not offered by the currently utilized vendor. All of the participant managers demonstrated an awareness of biodegradable alternatives and their benefits. This was reflected within the findings, as every manager had adopted at least one biodegradable alternative into their concession offerings (replacing single-use plastic straws with paper or biodegradable ones as an example). Specifically, all managers indicated that single-use bottle alternatives were not currently available from their key corporate partners. This was significant because managers consistently referred to the largest contributor of their plastic waste as coming from single-use bottles from corporate partners. Yet, and despite a range of bioplastic alternatives in the marketplace, they are being overlooked by the managers as such products are not offered by their key corporate partners. The managers deemed it inconvenient to purchase from outside their key corporate partnerships - especially as the current contracts involved sales targets. If advancing the purchase of bioplastic alternatives is predicated on convenience, then companies that currently offer alternatives must find a way to become mainstream and convenient. One strategy may include developing a comglomerate of small companies and approach sport facility managers as a group. Or, alternatively, find a way to link with a current mainstream partner.

The fifth conclusion was that participants noted seven key barriers in the process of deciding to use plastic alternatives. The barriers to utilizing plastic alternatives were wide-ranging. They included a general lack of biodegradable options from their current vendors; not being able to acquire all of the necessary components in a biodegradable form; not all supply companies offered the same types or variety of biodegradable alternatives; the lack of durability or rigidity of the products; sanitation issues for the use of spherification technology; that every participant had a corporate partnership with a beverage company resulting in use of single-use bottles, and in select cases, additional fountain beverages; and that incinerating plastic meant purchasing biodegradable options were not necessary. An interpretation is that strategies for overcoming such a range of barriers is necessary.

\subsection{Future Research and Final Thoughts}

Overall, sport is not exempt from being part of the solution concerning plastics in our global waterways. Yet, our examination of management perspectives relative to moving to plastic-free sport facility beverage service indicated that it is not self-regulation that will push the efforts forward. It is instead external forces - including government mandates and public pressure - that are needed to encourage an adaptation of practices. Further, 
strategies are required to overcome seven noted key barriers to the introduction of biodegradable alternatives at sport facility concessions. This research was limited to a study of concessions managers at Canadian sport facilities housing CHL tenants/teams and the findings indicate that there is much more to learn about the topic. For instance, additional studies could advance understandings around burdens of cost endured to mitigate plastics, both the figuration and by whom - how much of that cost would each stakeholder be willing to burden? Also, are geographical influences. Do the attitudes of patrons, managers, and local governments differ in big cities versus those located in smaller centres? As well, might proximity to major bodies of water influence attitudes concerning plastics? Time will reveal if those in sport were crucial in implementing solutions to the global plastic pollution issue.

\section{References}

Andersson, L., \& Bateman, T. (2000). Individual initiative: Championing natural environmental issues in U.S business organization. Academy of Management Journal, 43(4), 548-570. https://doi.org/10.5465/1556355

Auger, P., \& Devinney, T. M. (2007). Do what consumers say matter? The misalignment of preferences with unconstrained ethical intentions. Journal of Business Ethics, 76, 361-383. https://doi.org/10.1007/s10551-006-9287-y

Baldwin, R. (2010). Football and climate change: Strange bedfellows or a means of going beyond the usual suspects in encouraging pro-environmental behavioural change? Local Environment, 15(9), 851-866. https://doi.org/10.1080/13549839.2010.531252

Bansal, P., \& Gao, J. (2006). Building the future by looking to the past: Examining research published on organizations and environment. Organization \& Environment, 19, 458-478. https://doi.org/10.1177/1086026606294957

Barrett, A. (2018, September 10). PepsiCo Goes for Bioplastic Bottles. Bioplastics News. Retrieved from https://bioplasticsnews.com/2018/09/10/pepsico-goes-for-bioplastic-bottles/

Biswas, A. (2004). Integrated Water Resource Management: A Reassessment. Water International, 29(2). 248-256. https://doi.org/10.1080/0250806040869177

Borgert, T., Donovan, J., Topple, C., \& Eryadi, K. (2018). Corporate Sustainability Assessments: MNE engagement with sustainable development and the SDGs. Environmental Impact Assessment Review, 72, 99-107. https://doi.org/10.1016/j.eiar.2018.05.012

Brundtland Report. (1987). Our common future. Retrieved from https://www.sustainabledevelopment2015.org/AdvocacyToolkit/index.php/earth-summit

Carbery, M., O’Connor, W., \& Palanisami, T. (2018). Trophic transfer of microplastics and mixed contaminants in the marine food web and implications for human health. Environmental International, 115, 400-409. https://doi.org/10.1016/j.envint.2018.03.007

CBS. (2017). Target Field Among Leaders in Composting and Recycling; Asking Fans to Pitch In. Minnesota CBS Local. Retrieved from https://minnesota.cbslocal.com/2017/03/29/target-field-composting-recycling-green/

Coca-Cola. (2018, September, 10). Progress Against a World Without Waste: Holding ourselves accountable. Coca-colacompany.com. Retrieved

from https://www.coca-colacompany.com/news/progress-against-a-world-without-waste

Colabuono, F., Barquete, V., Domingues, B., \& Montone, R. (2009). Plastic Ingestion by Procellariiformes in Southern Brazil. Marine Pollution Bulletin, 58(1), 93-96. https://doi.org/10.1016/j.marpolbul.2008.08.020

De Pelsmacker, P., Driesen, L., \& Rayp, G. (2005). Do consumers care about ethics? Willingness to pay for $\begin{array}{lllll}\text { fair-trade coffee. Journal of Consumer } & \text { Affairs, } 363-385 .\end{array}$ https://doi.org/10.1111/j.1745-6606.2005.00019.x

De Villiers, M. (2003). Water: The Fate of Our Most Precious Resource. Toronto, Ontario: McClelland \& Stewart.

Dioguardi, B. (2012). How US pro sports teams rank on environmental disclosure. Green Biz website. Retrieved Feb. 22, 2012, from http://www.greenbiz.com/blog/2012/02/18/how-us-pro-sports-teams-rank-on-environmental-disclosure

Driedger, A. G. J., Dürr, H. H., Mitchell, K., \& Van Cappellen, P. (2015). Plastic debris in the Laurentian Great Lakes: A review. Journal of Great Lakes Research, 41(1), 9-19. https://doi.org/10.1016/j.jglr.2014.12.020 
Eriksen, M., Lebreton, L., Carson, H., Thiel, M., Moore, C., Bererro, J., ... Reisser, J. (2014). Plastic Pollution in the World's Oceans: More than 5 Trillion Plastic Pieces Weighing over 250,000 Tons Afloat at Sea. Public Library of Science, 19(12), 1-15. https://doi.org/10.1371/journal.pone.0111913

European Commission. (2018). A European strategy for plastics in a circular economy. European Commission. Retrieved from https://ec.europa.eu/environment/circular-economy/pdf/plastics-strategy-brochure.pdf

Frumkin, H. (2016). Environmental Health: From Global to Local. John Wiley and Sons.

Gaied, F., Louhichi, B., \& Jeday, M. R. (2017). Tertiary treatment of waste water by Electro-Fenton process: Economical study (pp. 1-4). 2017 International Conference on Green Energy Conversion Systems (GECS). https://doi.org/10.1109/GECS.2017.8066253

Gallella, A. (2013). Mastering the semi-structured interview and beyond: From research design to analysis and publication. New York, USA: New York University Press.

Gibbs, G. (2007). Analyzing Qualitative Data. Thousand Oaks, CA: Sage. https://doi.org/10.4135/9781849208574

Gibson, H., Kaplanidou, K., \& Kang, S. (2012). Small-scale event sport tourism: A case study in sustainable tourism. Sport Management Review, 15, 160-170. https://doi.org/10.1016/j.smr.2011.08.013

Gjuroska, E., \& Pantekovska, L. (2018). Effects of climate change on tourism and accent of some forms of sports tourism. Vizione, 31, 191-206.

Glesne, C. (2014). Becoming qualitative researchers: An introduction (5th ed.). Boston: Pearson.

Gorn, E. J., \& Goldstein, W. (1993). A brief history of American sports. New York: Hill and Wang.

Guest, G., Bunce, A., \& Johnson, L. (2006). How many interviews are enough? An experiment with data saturation and variability. Field Methods, 18, 59-82. https://doi.org/10.1177/1525822X05279903

G7/G8 Environmental Ministerial Meetings. (2018, September 20). G7 Innovation Challenge to Address Marine

Litter.

Retrieved

from

http://www.g7.utoronto.ca/environment/2018-environment-oceans-energy-marine-litter.html

Harder-Lauridsen, N., Kuhn, K., Erichsen, A., Mølbak, K., \& Ethelberg, S. (2013). Gastrointestinal illness among triathletes swimming in non-pollted versus polluted seawater affected by heavy rainfall. Denmark, 2010-2011. PLOS One, 1-9. https://doi.org/10.1371/journal.pone.0078371

Hardy, J., \& Skopeliti, C. (2019, April 13). London marathon runners to be given edible water bottles as organisers vow to cut down on plastic waste. The Telegraph UK. Retrieved from https://www.telegraph.co.uk/news/2019/04/13/london-marathon-runners-given-edible-water-bottles-organis ers

Jacobs, K., Petersen, L., Horisch, J., \& Battenfield, D. (2018). Green thinking but thoughtless buying? An empirical extension of the value-attitude-behaviour hierarchy in sustainable clothing. Journal of Cleaner Production, 1155-1169. https://doi.org/10.1016/j.jclepro.2018.07.320

Jambeck, J., Geyer, R., Wilcox, C., Siegler, T., Perryman, M., Andrady, A., ... Law, K. (2015). Plastic waste inputs from land into the ocean. Science, 347(6223), 768-770. https://doi.org/10.1126/science.1260352

Jarvis, C., \& Robinson, M. (2019, April 29). Is Canada's recycling industry broken? Global News. Retrieved from https://globalnews.ca/news/5199883/canada-recycling-programs/

Kallio, T., \& Nordberg, P. (2006). The evolution of organizations and the natural environment discourse: Some critical remarks. Organizations and the Environment, 19, 439-457. https://doi.org/10.1177/1086026606294955

Kaufman, P., \& Wolff, E. (2010). Playing and Protesting: Sport as a Social Vehicle for Change. Journal of Sport and Social Issues, 34(2), 154-175. https://doi.org/10.1177/0193723509360218

Kellett, P., \& Turner, P. (2011). CSR and water management in the sport sector: a research agenda. International Journal of Sport Management and Marketing, 10(1), 142-160. https://doi.org/10.1504/IJSMM.2011.043616

Kemp, R., Parto, S., \& \& Gibson, R. B. (2005). Governance for sustainable development: Moving from theory to practice. International Journal of Sustainable Development, 8(2), 12-30. https://doi.org/10.1504/IJSD.2005.007372

Kooi, M., Van Nes, E. H., Scheffer, M., \& Koelmans, A. A. (2017). Ups and downs in the ocean: Effects of 
biofouling on vertical transport of microplastics. Environmental Science and Technology, 51(14), 7963-7971. https://doi.org/10.1021/acs.est.6b04702

Koskijoki, M. (1997). My favourite things. In E. Van Hinte (Ed.), Eternally Yours: Visions on Product Endurance (pp. 132-143). Rotterdam: 010 Publishers.

Lane, B., \& Potter, S. (2007). The adoption of cleaner vehicles in the UK: Exploring the consumer attitude-action gap. Journal of Clean Production, 15, 1085-1092. https://doi.org/10.1016/j.jclepro.2006.05.026

Ma, A. (2019, May 8). The west has been dumping tens of millions of tons of trash in Southeast Asian countries for more than 25 years-now they want to send it back. Retrieved from https://www.businessinsider.com/southeast-asia-threaten-to-return-plastic-trash-to-west-2019-5

Mallen, C. (2018). Robustness of the sport and environmental sustainability literature: Where to go from here? In B. McCullough (Ed.), Handbook on Sport, Sustainability, and the Environment. New York: Routledge. https://doi.org/10.4324/9781315619514-2

Mallen, C., \& Chard, C. (2012, May). "What could be" in Canadian sport facility environmental sustainability. Sport Management Review, 15, 230-243. https://doi.org/10.1016/j.smr.2011.10.001

Mallen, C., Stevens, J., \& Adams, L. (2011). A content analysis of environmental sustainability research in sport management literature. Journal of Sport Management, 25(3), 240-256. https://doi.org/10.1123/jsm.25.3.240

Mason, S., Sutton, R., Stanek, S., Willis-Norton, E., Wren, I., \& Box, C. (2016). Microplastic contamination in San Francisco Bay, California, USA. Marine Pollution Bulletin, 109(1), 230-235. https://doi.org/10.1016/j.marpolbul.2016.05.077

Miller, R., Watts, A., Winslow, B., Galloway, T., \& Barrows, A. (2017). Mountains to the sea: River study of plastic and non-plastic microfiber pollution in the northeast USA. Marine. Pollution Bulletin, 124(1), 245-251. https://doi.org/10.1016/j.marpolbul.2017.07.028

Moore, C. (2019). Plastic Pollution. Encyclopaedia Brittanica. Retrived from https://www.britannica.com/science/plastic-pollution

Morse, J. M. (2015). Data where saturated. Qualitative Health, 25, 587-588. https://doi.org/10.1177/1049732315576699

National Geographic. (2019). Great Pacific Garbage Patch. Retrieved from https://www.nationalgeographic.org/encyclopedia/great-pacific-garbage-patch/

Nazemi, A., \& Madani, K. (2018). Urban water security: Emerging discussion and remaining challenges. Sustainable Cities and Society, 41, 925-932. https://doi.org/10.1016/j.scs.2017.09.011

Newcomb, T. (2020, January 28). Adidas Primeblue recycled marine waste filling new Miami football field, clothing line. Retrieved from https://www.forbes.com/sites/timnewcomb/2020/01/28/adidas-primeblue-recycled-ocean-plastic-waste-filli ng-new-miami-football-field-clothing-line/\#582772396acc

Nikolic, N., Steffen, R., \& Bilic-Zulle. (2017, October). Epidemiology and impact of travellers' diarrhoea on participants in the pre-Olympic test event in Qquec Rio 2015. Research Letter: British Journal of Sports Medicine, 51, 21. https://doi.org/10.1136/bjsports-2017-098003

Notpla. (n.d.). We make packaging disappear. Retrieved from https://www.notpla.com

Okoli, C., \& Pawloski, S. (2004). The Delphi method as a research tool: An example, design considerations and applications. Information \& Management, 42, 1-29. https://doi.org/10.1016/j.im.2003.11.002

Orr, M., McCullough, B. P., \& Pelcher, J. (2020, July). Leveraging sport as a venue and vehicle for transformative learning. Journal of Sustainability in Higher Education, 21(6), 1071-1086. https://doi.org/10.1108/IJSHE-02-2020-0074

PepsiCo. (2020, May 6). Sustainability Initiatives: Packaging. Retrieved from https://www.pepsico.com/sustainability/packaging

Paquette, J., Stevens, J., \& Mallen, C. (2011). The IOC: An interpretation of environmental sustainability, 1994-2008. Sport in Society, 14(3), 355-369.

Patton, M. (2002). Qualitative research and evaluation methods (3rd ed.). London: Sage. 
Phillips, P., \& Turner, P. (2014). Water management in sport. Sport Management Review, 17(3), 376-389. https://doi.org/10.1016/j.smr.2013.08.002

Royer, S.-J., Ferro., S., Wilson, S. T., \& Karl, D. M. (2018). Production of methane and ethylene from plastic in the environment. PLoS ONE, 13(8), e0200574. https://doi.org/10.1371/journal.pone.0200574

Russell, K. (1997). Wasting water in the Northwest: eliminating waste as a way of restoring streamflows. Environmental Law, 27(1), 151-201.

Sartore-Baldwin, M., \& McCullough, B. (2018). Equity-based sustainability and ecocentric management: Creating more ecologically just sport organization practices. Sport Management Review, 21, 391-402. https://doi.org/10.1016/j.smr.2017.08.009

Schuyler, Q., Hardesty, B., Lawson, T., Opie, K., \& Wilcox, C. (2018). Economic Incentives Reduce Plastic Inputs to the Ocean. Marine Policy, 96, 250-255. https://doi.org/10.1016/j.marpol.2018.02.009

Siegel, R. P. (May, 19, 2019). The Rise of Plant-Based Packaging. GreenBiz. Retrieved from https://www.greenbiz.com/article/rise-plant-based-plastic-packaging

Smith, C. (1992). Introduction: Inferences from verbal material. In P. S. Charles (Ed.), Motivation and personality: Handbook of thematic content analysis (pp. 1-17). Cambridge: Cambridge University Press. https://doi.org/10.1017/CBO9780511527937.002

Smith, L. (2018). Plastic ingestion by Scyliohinus canicular trawl captured in the North Sea. Marine Pollution Bulletin, 130, 6-7. https://doi.org/10.1016/j.marpolbul.2018.03.001

Spector, S., Chard, C., \& Mallen, C. (2012). Socially Constructed Environmental Issues in Sport: A Content Analysis of Ski Resort Environmental Communications. Unpublished master's thesis, Brock University, St Catharines, Ontario. https://doi.org/10.1016/j.smr.2012.04.003

Sproles, G., Geistfeld, L., \& Badenhop, S. (1978). Informational Inputs as Influences on Efficient Consumer Decision-Making. Journal of Consumer Affairs, 12(1), 88-103. https://doi.org/10.1111/j.1745-6606.1978.tb00635.x

Stake, R. (1995). The Art of Case Study Research. Thousand Oaks: CA, Sage Publications.

Syred, M. (2018, April 20). [Webpage]. London Marathon using recyclable cups to cut plastic waste. BBC News. Retrieved from https://www.bbc.com/news/business-43830058

Teuten, E., Rowland, S., Galloway, T., \& Thompson, R. (2007). Potential for Plastics to Transport Hydrophobic Contaminants. Environmental Science and Technology, 22(41). https://doi.org/10.1021/es071737s

Twickenham Stadium. (n.d.). Twickenham Fan Cup. Retrieved from https://www.facebook.com/twickenhamstadiumofficial/videos/-the-twickenham-fan-cup-providesa-cleanerstadium-and-reduces-waste-a-quality-cu/445752652637976/

United Nations Environment Programme. (2018, May 7). 10 Ways the world of sport is tackling plastic pollution. Retrieved from https://www.unenvironment.org/news-and-stories/story/10-ways-world-sport-tackling-plastic-pollution

United States Geological Survey. (2018). How Much of Earth's Water is Stored in Glaciers? Retrieved from https://www.usgs.gov/faqs/how-much-earths-water-stored-glaciers?qt-news_science_products=3\#qt-news_s cience_products

Waste Management. (2013). Sustainable Stadiums \& Arenas. Waste Management, Inc. Retrieved Dec. 8, 2015, from https://www.wm.com/sustainability-services/documents/insights/Stadiums\%20and\%20Arenas\%20Insight.p df

Wicker, P. (2018). The carbon footprint of active sport tourists: an empirical analysis of skiers and boarders. Journal of Sport \& Tourism, 2, 151-171. https://doi.org/10.1080/14775085.2017.1313706

World Economic Forum. (2018). Global Plastic Action Partnership. Weforum.org. Retrieved from https://www.weforum.org/projects/global-plastic-action-partnership. 


\section{Appendix A}

\section{The Interview Guide}

- It is understood that you manage the procurement for the liquids/fluids distributed at the sport facility .... Tell me about the sales of liquids/fluids served at the sport facility that involves the use of plastics (such as plastic bottles, cups, lids and straws)

- If you were to quantify the amount of plastics within beverage services ordered annually how many: plastic bottles, cups, lids and straws are ordered?

- Do you have any beverages served that do not involve the use of plastics?

- Tell me about the policies that concern the use of plastics in the sport facility for beverage services.

- Tell me about the management of the plastics waste.

- What options do you know about that could aid in the mitigation/removal of plastics for beverage services?

- Have you considered any plastics options that are biodegradable?

- What about the use alternatives - such as water pods?

- What implementation issues arise, if any, if plastics were replaced with biodegradable options?

- What is your position concerning the need to mitigate/remove plastics from the beverage service?

- Do you currently have any directives or policies concerning working towards the mitigation or removal of plastics for beverage service at the sport facility?

- If so, what are they?

- Are there any pressures on those managing beverage services at sport facilities in Canada to reduce plastics use?

- What changes, if any, do you foresee/envision concerning mitigating/removal of plastics at the sport facility for beverage services?

- What are the barriers to obtaining these visions?

- How can those involved in sport facility adapt to incorporate the mitigation/removal of plastics use?

- How does change happen in beverage management?

- If concessions went to a plastic free state; what changes would be needed?

- If plastic-free programming were to be implemented at your facility, how would it impact your business model?

\section{Copyrights}

Copyright for this article is retained by the author, with first publication rights granted to the journal.

This is an open-access article distributed under the terms and conditions of the Creative Commons Attribution license (http://creativecommons.org/licenses/by/4.0/). 